\title{
Coral Reef Restoration and Artificial Reef Management, Future and Economic
}

\author{
Mohammed Shokry Ahmed Ammar*
}

National Institute of Oceanography and Fisheries, Red Sea and Gulfs of Suez \& Aqaba Branch, Suez, P.O. Box 182, Egypt

\begin{abstract}
On a global scale, the value of the total economic goods and services provided by coral reefs have been estimated to be US $\$ 375$ billion per year with most of this coming from recreation, sea defence services and food production, this equates to an average value of around US $\$ 6,075$ per hectare of coral reef per year. Degradation of reefs means the loss of these economic goods and services, and the loss of food security and employment for coastal peoples, many of them in developing countries and many of them living in poverty. In a healthy reef system which has not been physically damaged, an impacted area might be expected to recover naturally to its pre-disturbance state along a successional trajectory. If degradation is sufficiently severe or spatially extensive, then active restoration e.g. transplantation, in combination with management actions to reduce anthropogenic stress are necessary. Recoverability depends on the stressor, the impacted species/community and the temporal and spatial intensities of the stressor. Artificial reef is any structure built or placed on the sea bed, water column or floating on its surface, with the purpose of creating a new attraction to scuba divers or to concentrate or attract plants or animals for fishing purposes. These artificial reefs can be designed for different purposes like: (1) Tourism \{SCUBA diving, recreational angling, surfing and beach enhancement $\}$ (2) Fisheries (3) Nature conservation (4) Science. This paper reviews conditions driving the need for restoration, and the questions that must be considered to identify the type of restoration necessary or possible. Artificial reefs around the world, their uses, social and economic impacts, liability, the use of novel technology approaches in artificial reefs and future applications were also reviewed. Artificial reefs can have positive economic impacts which are significant and may be several hundreds of million dollars per year. For future application, need is urgent for: 1- Link biological, physical and economic issues within reef development 2-Continue biological and engineering research to refine reef design and modeling.
\end{abstract}

\section{INTRODUCTION}

On a global scale, the value of the total economic goods and services provided by coral reefs have been estimated to be US $\$ 375$ billion per year with most of this coming from recreation, sea defence services and food production, this equates to an average value of around US $\$ 6,075$ per hectare of coral reef per year [1]. Degradation of reefs means the loss of these economic goods and services, and the loss of food security and employment for coastal peoples, many of them in developing countries and many of them living in poverty.

The Status of Coral Reefs of the World (2004) Report [2] estimates that $20 \%$ of the world's coral reefs have been effectively destroyed and show no immediate prospects of recovery, that $24 \%$ of the world's reefs are under imminent risk of collapse through human pressures, and that a further $26 \%$ are under a longer term threat of collapse. The major observed threats to the world coral reefs are indicated in Fig. (1).

A case study [3] on the total net benefits and quantifiable losses due to threats to coral reefs in Indonesia present value;

*Address correspondence to this author at the National Institute of Oceanography and Fisheries, Red Sea and Gulfs of Suez \& Aqaba Branch, Suez, P.O. Box 182, Egypt; Tel: 002010 2660980; E-mail: shokry_1@yahoo.com
$10 \%$ discount rate; 25 year time-span) is indicated in Table 1.

Our "assistance" to natural recovery may be either in the form of passive or indirect measures, or in the form of active or direct interventions, the former generally involve improving the management of anthropogenic activities that are impeding natural recovery processes, the latter generally involve active physical restoration and/or biological restoration interventions (e.g., transplantation of corals and other biota to degraded areas) [4].

With reefs we are usually aiming for restoration but may be pleased if we can just achieve some form of rehabilitation. The aims of reef restoration are likely to be dictated by economic, legal, social and political constraints as well as ecological realities, however, ignoring the latter means a high risk of failure [5].

It is worth mentioning that Reefs stressed by anthropogenic activities (e.g., overfishing, sediment and nutrient runoff) are less likely to be able to recover from large scale disturbances. Active restoration is highly unlikely to be able to assist such recovery due to the huge scale-mismatch, but good coastal management (referred to by some as "passive restoration") may give them a fighting chance.

We should further encourage disseminating the success, failures, and lessons learnt in order to help others to get advantage from your experiences. 

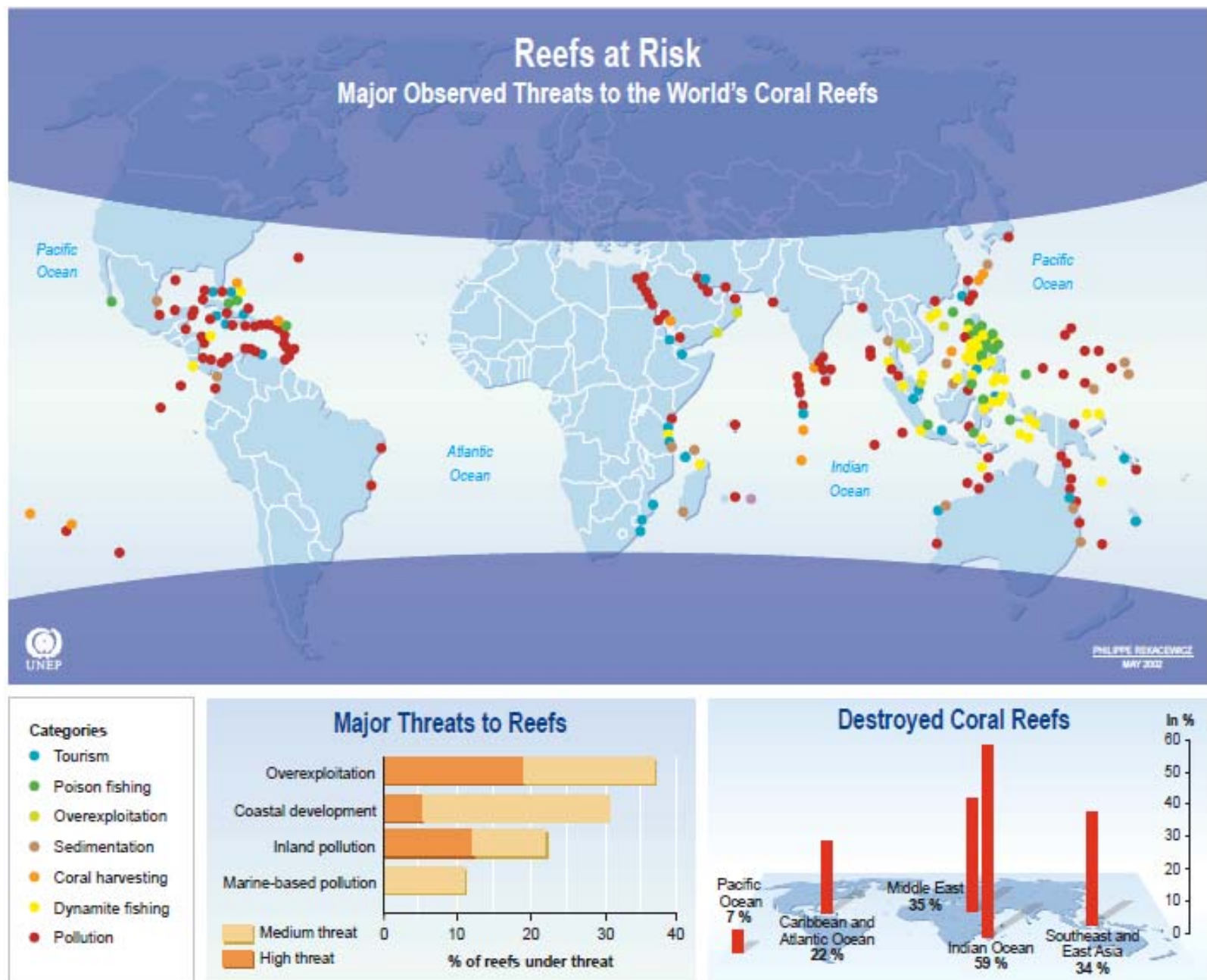

Source: Bryant et al., Reefs at Risk; a Map-Based Indicator of Threats to the World's Coral Reefs, World Resources Institute (WRI). Washington DC, 1898.

Fig. (1). Major observed threats to the world coral reefs.

Table 1. Total Net Benefits and Quantifiable Losses Due to Threats to Coral Reefs in Indonesia (Present Value; $10 \%$ Discount Rate; 25 Year Time-Span) [3]

\begin{tabular}{|c|c|c|}
\hline Threat & Total net Benefit to Individual & Total net Losses to Society \\
\hline Blast fishing & $\$ 15,000$ per $\mathrm{km}^{2}$ & $\$ 98,000-761,000$ per $\mathrm{km}^{2}$ \\
\hline Coral mining & $\$ 121,000$ per $\mathrm{km}^{2}$ & $\$ 176,000-903,000$ per $\mathrm{km}^{2}$ \\
\hline Sedimentation from logging & $\$ 98,000$ per $\mathrm{km}^{2}$ & $\$ 273,000$ per $\mathrm{km}^{2}$ \\
\hline
\end{tabular}

\section{RESTORATION OF DAMAGED NATURAL REEFS}

\section{II.1. Active and Passive Restoration Measures}

The primary aim of restoration is to improve the degraded reef in terms of ecosystem structure and function. Attributes to be considered might be biodiversity and complexity on one hand and biomass and productivity on the other [1]. In a healthy reef system which has not been physically damaged, an impacted area might be expected to recover naturally to its pre-disturbance state along a succes- sional trajectory [6]. In such a case, benign "neglect" (letting nature take its course) and patience may achieve restoration. However, if degradation is sufficiently severe or spatially extensive, or the reef system is subject to additional chronic human-induced stresses (e.g., overfishing, nutrient loading, sedimentation) then "neglect" (doing nothing) may see further decline, or possibly a switch to an alternate (perhaps undesirable for local resource users) stable state (e.g., a reef dominated by macroalgae). In such cases, active restoration, if necessary, in combination with management actions to 
Table 2. Conditions Driving the Need for Restoration, and the Questions that must be Considered to Identify the Type of Restoration Necessary or Possible (Modified and Expanded From [13]

\begin{tabular}{|c|c|}
\hline Conditions Driving the Need for Restoration & Questions Which Help Define Restoration Approach \\
\hline
\end{tabular}

reduce anthropogenic stress, is likely to be needed if the reef is to have any chance of recovery to a desirable state. Even with active restoration measures, recovery may progress to some state different from the original ecosystem [4]. However, restoration ecology suggests the notion of active measures, while conservation biology focuses on "passive" measures, allowing natural processes to mitigate impacts without or with only minimal human interference [7]. During the past decade, coral transplantation measures have frequently been employed and have gained recognition as the prime management tool for reef restoration [7].

\section{II.2. Recovery}

The large number of schemes and studies, has led to a detailed but sometimes confusing semantics of restoration with an inconsistent, conflicting and sometimes overlapping application and interpretation of the terms [8]. Further understanding of these terms, approaches and their application requires many fundamental questions to be answered [9] Table 2. The term recovery implies that a system will return to a previous condition after being in a degraded or disrupted one, which is often interpreted as being in poor ecological health. The recovery may occur naturally but of course may be speeded up with intervention implying that recovery will occur in the system once the stressor is removed; it can be encouraged by management actions or is the response to management actions. If recovery is truly successful then the community established will be similar in species composition, population density and size and biomass structure to that previously present or present at a comparable (unimpacted, unaffected) site [10]. The ecosystem goods and services provided and its carrying capacity will have been recovered or been regained to the pre-impact state. Despite this, it is questioned whether the original state can ever be achieved even if it is known [8]; it is more likely that the recovery will be evaluated using single or sets of structural, functional or socio-economic indicators of recovery, which may or may not return to pre-impact states, whether known or not.

\section{II.3. Recoverability}

Recoverability can be defined as 'the ability of a habitat, community or individual (or individual colony) of species to redress damage sustained as a result of an external factor' [11]. It is an inherent property of the ecosystem in that certain ecosystems may have a greater potential for recovering from stress than others; for example, a mobile subtidal sandbank whose physical and biological structures created by a high-energy regime will have greater recoverability than more stable areas to anthropogenic causes of change such as beam-trawling or aggregate extraction [12]. However, such communities may be less resilient to disturbance by other stressors such as organic enrichment; hence recoverability depends on the stressor, the impacted species/community and the temporal and spatial intensities of the stressor.

\section{II.4. Rehabilitation vs Restoration}

Rehabilitation can be defined as "the act of partially or, more rarely, fully replacing structural or functional characteristics of an ecosystem that have been reduced or lost'. It may also be the substitution of alternative qualities or characteristics than those originally present with the proviso that they have more social, economic or ecological value than existed in the disturbed or degraded state [9]. Thus, the rehabilitated state is not expected to be the same as the original state or as healthy but merely an improvement on the degraded state [14].

Ecosystem restoration has been defined by [15] as 'activities designed to restore an ecosystem to an improved condition. However, this does not imply the highest quality of the final ecosystem but merely that it is better than the degraded situation. Because of this, a preferable definition of restoration is 'the process of re-establishing, following degradation by human activities, a sustainable habitat or ecosystem with a natural (healthy) structure and functioning' [14, 16]). Simenstad et al. (2006) [8] take this to be returning an ecosystem to its pre-disturbance condition and functioning and Bradshaw (2002) [14] suggests that although the nonecological uses of the term imply a return to an original state which is perfect and healthy, an ecologically preferable definition is 'the process of assisting the recovery and management of ecological integrity. Restoration can accelerate recovery although this could lead to an alternative state. Also the original state may not be known [8] and so the desired 
state will be a best guess, subjective or valued judgement [17]. Fonseca et al. (2002) [18] make the further distinction between compensatory restoration and primary restoration. The former refers to any action taken to compensate for interim losses of natural resources and services that occur from the point of injury until the recovery of those resources/ services to baseline. Conversely, primary restoration refers to actions that return the injured natural resources and services to baseline.

\section{II.5. Restoration of Ship Grounding Sites}

Efforts to restore reef sites damaged by ship grounding include activities such as salvaging coral colonies, coral fragments, and sponges, removing loose debris from the reef floor, reconstructing 3-D structural complexity of the reef, and reattaching detached corals and sponges to cleared reef substrates or specially designed artificial reef structures [1921]. A major difference in this type of reef restoration, as compared to other restoration measures, is that most, if not all, coral material for restoration comes from the damaged sites and not from adjacent coral reef populations. Another challenge to tackle is the massive amounts of rubble. The options include: (a) leaving it in place and stabilizing it with cements; (b) moving it far from the site and dumping it in deep water; or (c) reconfiguring it by moving it off reef and building piles where it can do no harm. After removing the debris from the reef platform, corals and other sessile benthic organisms can be transplanted on the damaged area $[19,21]$.

Miller and Barimo [22] hypothesized that differences in algal assemblages resulted from varying structural designs (differing material, surface texture, and/or surface orientation) that mediated differential coral recruitment success at the two sites. Despite the abundant resources spent on ship grounding restoration projects, the lack of clear scientific goals, the need for hypothesis-driven monitoring efforts, and a general lack of tools to assess restoration success have hindered progress in the reef restoration field [21, 23, 24].

\section{II.6. Coral Transplantation}

\section{II.6.1. Coral Transplantation Measures}

During the past decade, coral transplantation measures have frequently been employed and have gained recognition as the prime management tool for reef restoration [7]. Several types of source material are available for transplantation. These include: transplantation of small or large, whole coral colonies $[6,25]$, enhanced by deliberate seeding of planula larvae [26, 27], transplantation of coral branches or fragments [26, 28, 29, 30-35] and the transplantation of nubbins [36-41].

Several studies discussed different facets and parameters for the rationale of coral transplantation: (a) choice of coral species $[42,43]$. (b) transplantation efficacy as compared to natural recruitment processes and rates [7]. (c) colony pattern formation [42]; (d) major goals for impacts of specific restoration acts on donor reef areas [7, 42]. (e) survivorship of transplanted coral material [25, 43,]. (f) growth rates of transplanted colonies as compared to naturally recruited colonies $[25,43]$. (g) the type of substrate $[7,25,43])$ and (h) the drawback of reduced fecundity in transplanted and/or donor colonies [42].
Ecologically sound management of coral transplantation should consider the growth and mortality rates of transplants in relation to their sizes. Although studies have yielded variable results, possibly due to the use of different species, divergent protocols employed, and various habitats restored, most outcomes confirmed size-dependent survivorship [26, 28, 30, 38, 39, 40, 44]. The generalization of size-dependent growth rate and size dependent pattern formation had also been studied and has already guided several transplantation operations [28, 42]. Coral transplantation measures might be more effective when combined with other management measures such as substrate stabilization, either by conventional protocols $[30,35,41,45]$, by electrochemical deposition of calcium carbonate [39, 40, 46]. Dispersing coral branches or attaching coral fragments onto unstable rubble or coarse sand were ineffective for restoring coral sites (except in specific cases of sheltered areas [30]. In those unstable substrates, natural based recruitment processes were inhibited because settled coral colonies were either buried or smothered by the loose substrate $[31,35]$.

Transplantation of coral colonies/fragments onto denuded reef areas is, therefore, best employed when: (a) disturbed reef area undergoes a "phase shift" to communities dominated by soft corals or macroalgae (that limit recovery of hard coral colonies [41]; (b) when natural recruitment is unlikely or limited, resulting from diminution of planula larvae as a source material, or from the existence of unconsolidated substrate [35]; and (c) when enough material of donor coral colonies is available [47, 48, 30].

\section{II.6. 2. Coral Nurseries}

The concept of nursery installed on the sea floor has already been applied to corals [28, 42, 49].

One of the major ex situ restoration approaches is the collection, settlement, and maintenance of planula larvae and spats under optimal conditions $[6,50]$. The in situ nursery approach sustains the mariculture of nubbins, coral fragments, and small colonies. A protected nursery phase (gardening) provides the transplanted material with an acclimation period, essential for increasing post transplantation survivorship and growth to size suitable for transplantation. The transplantation of nursery-grown "propagules" back into their natal reef helps in preventing genet and species extinctions in degrading sites, thus exercising the "rescue effect" on a local scale, it also preserves the genetic heterogeneity of coral populations [7].

A coral nursery may also be considered as a pool for local species that supplies reef-managers with unlimited coral colonies for sustainable management [7, 29, 42].

In situ coral nurseries can supply transplantation operations with corals adapted to natural reef conditions, while ex situ coral nurseries may facilitate the yield from coral planulae, increasing genetic variability of transplanted colonies [49]. Both ex situ and in situ approaches can also provide ample material for the coral trade, thus reducing collections of coral colonies from the wild [51]. Heeger and Sotto [52] stated that, the cheapest route for coral propagation is to collect corals directly from the reef and transplant to the degraded area. 


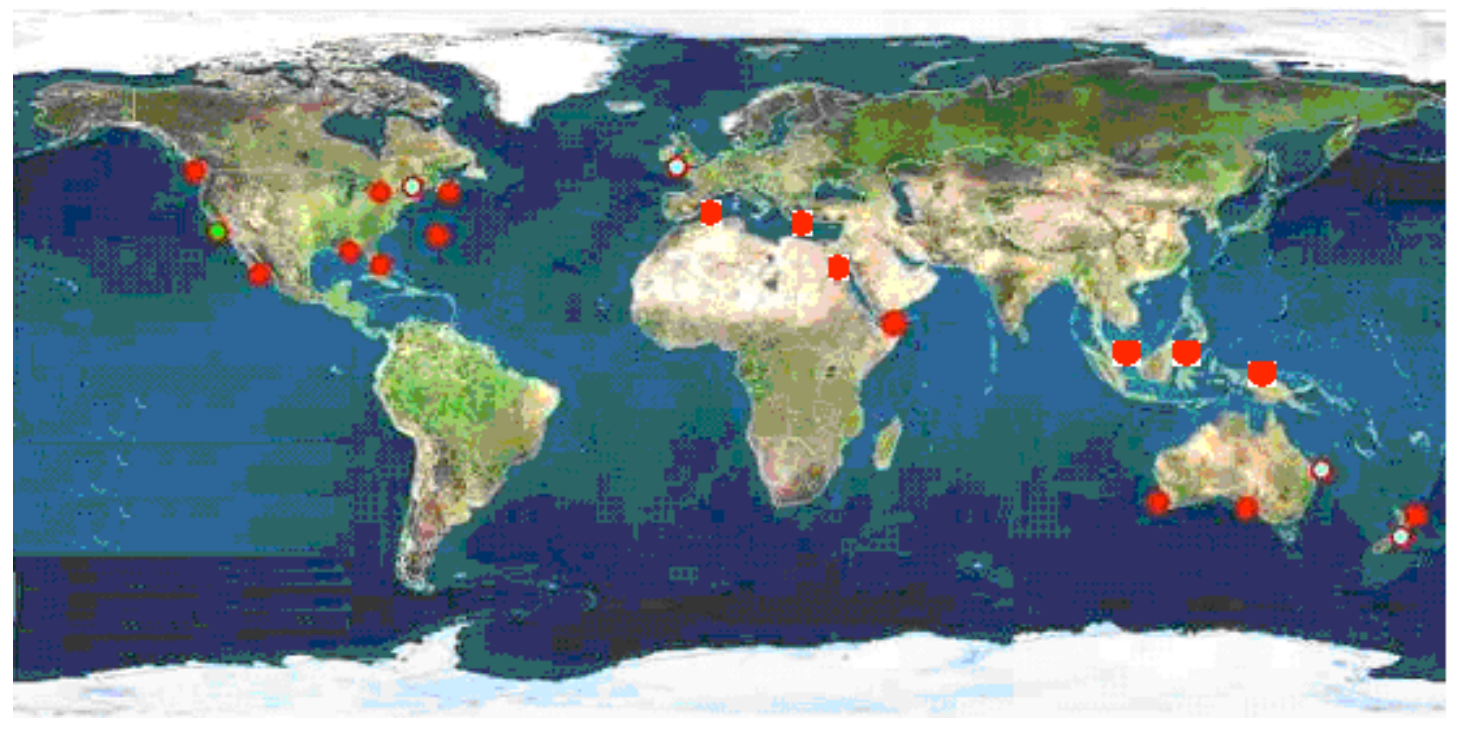

Fig. (2). Major artificial reefs around the world.

\section{ARTIFICIAL REEFS}

\section{III.1. Definitions}

Many formal definitions available to use, often worded to promote a particular philosophy. Australian Great Barrier Reef Marine Park defined artificial reef as "any structure built or placed on the sea bed, water column or floating on its surface, with the purpose of creating a new attraction to scuba divers or to concentrate or attract plants or animals for fishing purposes"; International Conventions on the protection of the marine environment, (OSPAR and Barcelona Conventions) defined it as "a submerged structure with a deliberate placement on the sea bed to imitate some of the characteristics of a natural reef. Some parts of the reef can be partially exposed in different tidal situations"; The European Artificial Reef Research Network (EARRN) defined artificial reef as "any structure that has been deliberately submerged on the substrate (sea bed) to imitate some of the characteristics of natural reefs ". The most encompassing definition is the Australian definition, the others all exclude floating devices, new definitions will arise as technology develops.

\section{III.2. Materials of Artificial Reefs}

Artificial reefs encompass a wide range of structures from specially engineered and prefabricated reef structures to "materials of opportunity" such as white goods and tires, and in recent years unwanted oil and gas recovery structures [53]. Many of the huge variations in the engineering designs, applications and uses of artificial reefs are shown in Figs. (36).

\section{III.3. Artificial Reefs Around the World}

Major artificial reefs around the world are shown in Fig. (2). At least 40 countries have deployed artificial reefs [54]. Japan leads the world in artificial reef technology to increase commercial fishery yields and production, whereas the Philippines widely use reef structures for artisanal fishery activities. North America and Australia use artificial reefs predominantly for recreational activity including fishing and diving. European artificial reefs are generally in the development stage but include a number of research reefs and artificial reefs for trawler exclusion [53, 55]. Artificial reef history in the United States of America has been well documented due to years of intense public interest leading to the deployment of an extensive artificial reef network (Florida is the leading state with over 1500 artificial reefs [56]. Europe has also made a concerted effort to ensure responsible and effective artificial reef development through creation of the European Artificial Reef Research Network (EARRN) in 1995 (funded by the European Commission). The objectives of EARRN include, but are not limited to, promoting regional collaboration, promoting awareness of issues, and guiding future research on artificial reefs (reviewed in Sutton and Bushnell [57]). In Egypt, good and novel approaches were use like the application of molecular biological tools to select sites for rehabilitation [36] or designing and deploying the artificial reef in such a way that one environmental disadvantage like sedimentation would be used for building the artificial reef i.e. dealt with as an advantage rather than being a disadvantage [37].

\section{III.4. Uses of Artificial Reefs}

To date, artificial reefs have not proven to be an efficient restoration tool, neither when used for transplantation measures nor when left for natural recruitment [58]. For over 20 years, Schuhmacher [59] followed several artificial reefs in Eilat, Red Sea, established some 30 years ago. That long term study revealed that none of the artificial reefs developed coral communities on the 3-D profile. The artificial reefs had not been covered by corals during the long period and were limited in coral recruits as compared to adjacent natural habitats. From the review of literatures different uses of artificial reefs can be outlined as follows: (1) Tourism (2) Fisheries (3) Nature conservation (4) Science

(1) Tourism: A - SCUBA diving B - Recreational Angling C-Surfing D - Beach enhancement 

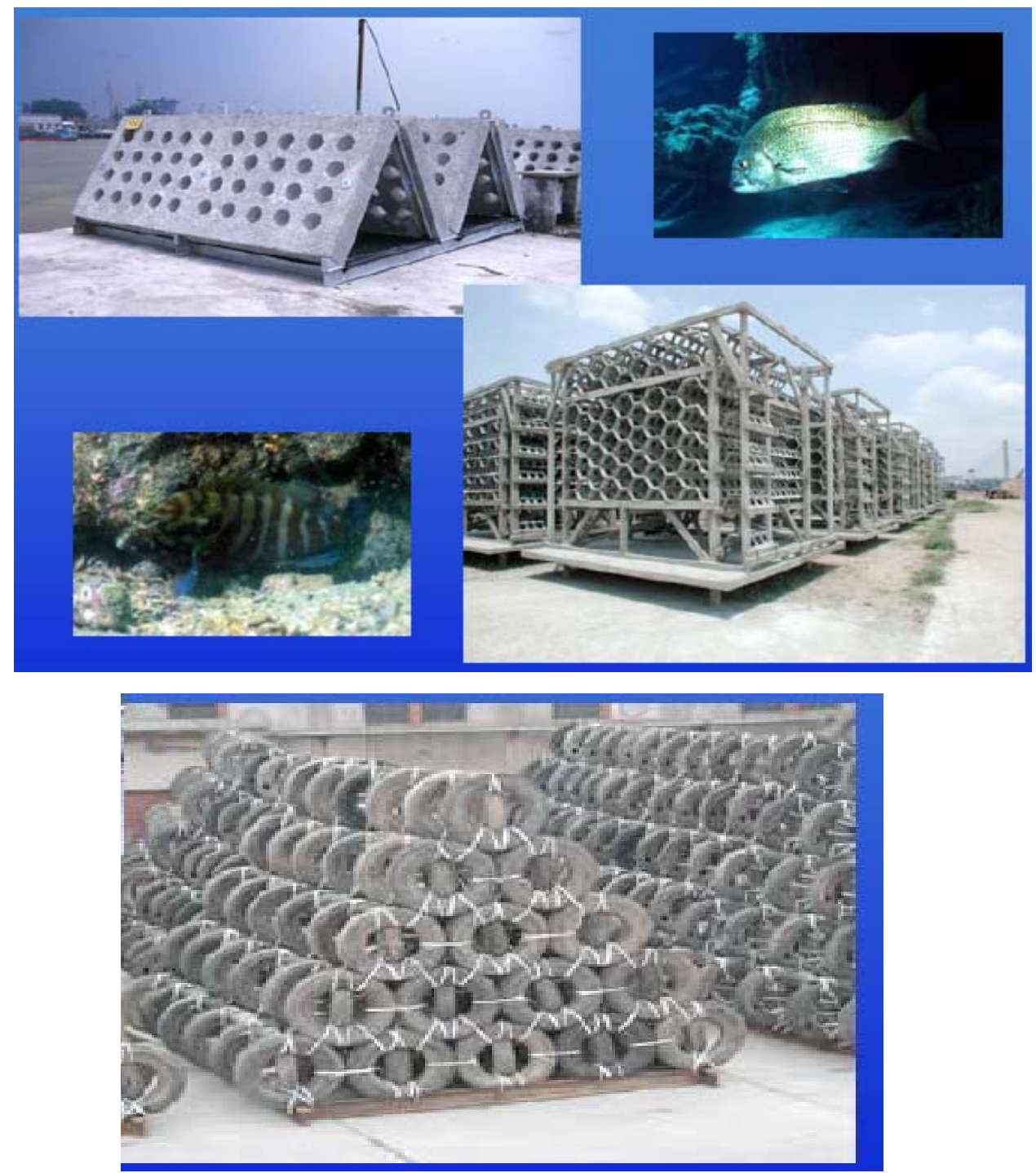

Fig. (3). Many of the huge variations in the engineering designs and applications of artificial reefs used for fisheries around the world.

(2) Fisheries: It includes huge variation in applications around the world and needs to question attraction and exploitation rates to ensure overfishing isn't the end result

(3) Nature conservation: Three levels are considered: a) protect what exists b) mitigate for unavoidable damage caused by very important infrastructure c) restore damaged habitat to provide a new community/habitat

(4) Science: It can be reef technology focused, needed if reefs are to develop and target their aims effectively, needed to 'audit' the 'performance' of a reef against its build targets, diving scientists often involved with, used in fish census, epifaunal monitoring and commercial species survey

\section{III.5. Substrate Stabilization}

A variety of material and methodologies has been used for substrate stabilization. Much of the work has been done with artificial material laying on top or attached to the reef substrate, preferably concrete (usually reinforced with steel) or natural rock $[41,45,59,60]$. Others claim success with cheaper and less laborious methods, such as lashing corals to seabed to form a grid or fixing with epoxy resin (Ammar et al. [36]. Depositing $\mathrm{CaCO}_{3} / \mathrm{Mg}(\mathrm{OH})_{2}$ onto steel frames or onto other conductive material and administering low voltage direct current $(<24 \mathrm{~V})$ was employed by several working groups [20, 39, 40, 46, 59, 61]. Ammar [62] indicated that the DNA strand break (SSF) of the Red Sea reef coral Stylophora pistillata is improved by using ARCON $^{\circledR}$ substrate produced by electrolysis of seawater. Goreau et al. [46] also suggested three hypotheses for enhancing growth of corals that are under this low current state: (a) electric field enables carbonate accretion and may cause the precipitated carbonates to attach directly to the skeletons of coral transplants; (b) low current induces $\mathrm{CaCO}_{3}$ enrichment of water in the immediate vicinity of the coral, thereby enhancing natural calcification; and (c) excess production and release of electrons, due to the electrochemical processes occurring in the coral vicinity, might affect the electron transport chain for ATP production, where the excess energy could be used for 


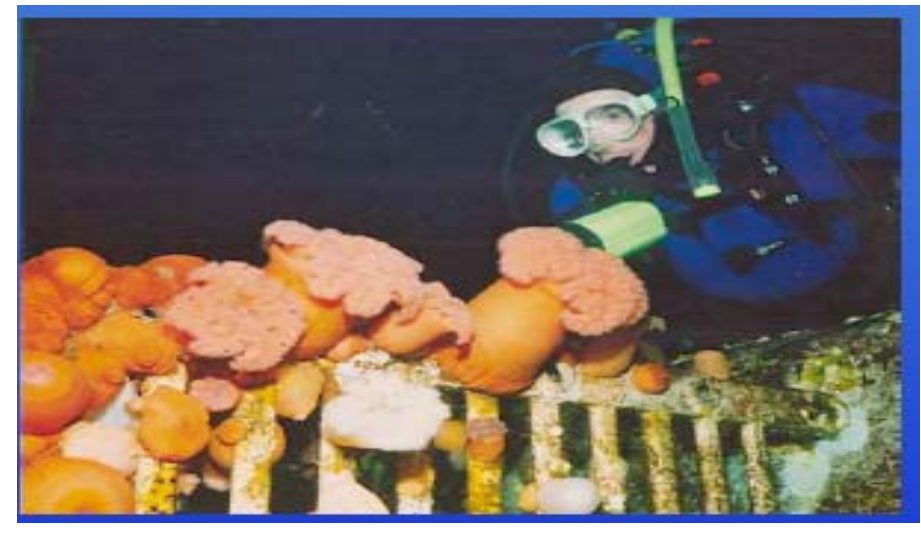

Fig. (4). A sunken ship, prepared specifically for divers to explore.

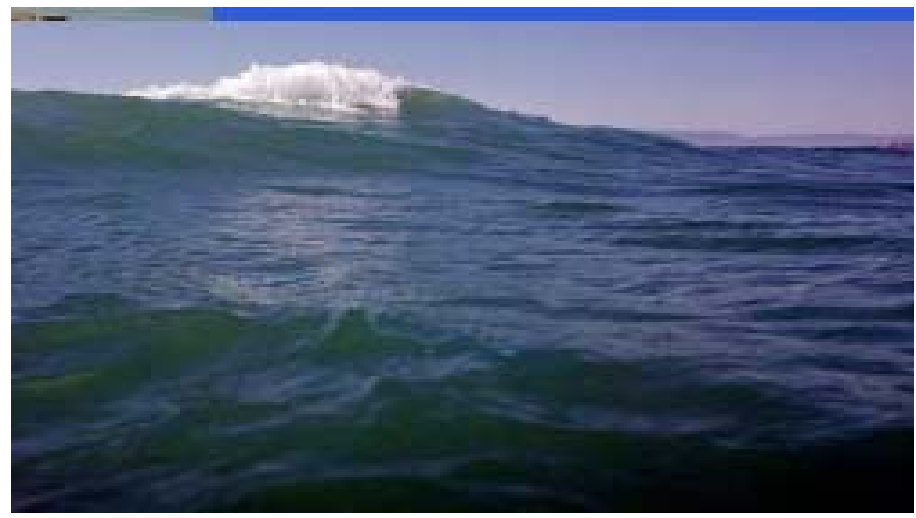

Fig. (5). Artificial reefs promote breaking of waves in situations where the surf would be poor.

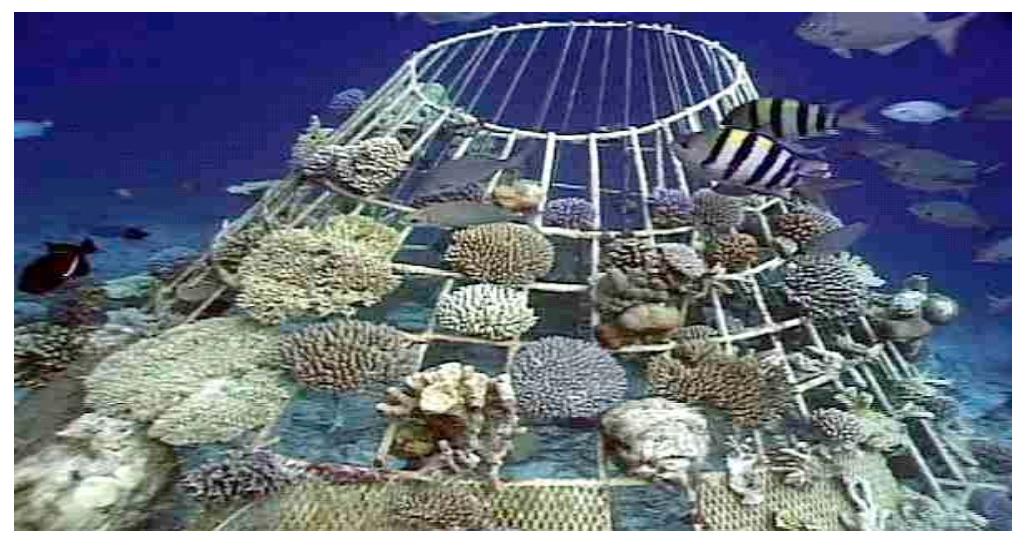

Fig. (6). Barnacle Reef, Maldives, 1997, in which $\mathrm{CaCO}_{3} / \mathrm{Mg}(\mathrm{OH})_{2}$ were deposited onto steel conductive material.

growth enhancement. Recent studies that had tested these hypotheses Numerous authors [20, 39, 40, 59], although documenting high survivorship of attached coral branches, did not reveal an ubiquitous accelerated calcification by live corals, or resulted in lateral growth at the base of branches instead of a longitudinal increas.

\section{III.6. Biogeochemical Processes and Nutrient Cycling Within an Artificial Reef}

One of the reasons for the poor understanding of AR (artificial reef) ecology is the lack of knowledge of their effect on the surrounding natural environment [63, 64], which is a fairly new area of AR research.
Reef structures, by providing protection for marine species, can result in marine system biomass enhancement [65]. As a result of biomass enhancement, sediment becomes more active in the process of nutrient regeneration providing a nutritional source for other forms within the ecosystem, or being exported by water movements increasing the general productivity of neighbouring areas, furthermore, planktivorous fish species can induce nutrient production in the water column, excreting substantial amounts of ammonium, urea and depositing organic material, which is then incorporated into the reef food web [66]. 


\section{III.7. Recruitment of Benthic Organisms onto an Artificial Reef}

Unplanned ARs, such as sunken ships, oil and gas platforms and breakwaters, offer substratum for settlement of benthic invertebrates and fish. This type of AR is common worldwide and can be considered as a natural experiment in community development on ARs, accessible for monitoring [67-69]. Nowadays, most ARs are purpose-planned structures, built according to accepted principles of safety, durability and effectiveness [53, 70]. When designing ARs several factors should be taken into consideration, including type of materials [53], size and orientation [68]. The environmental factors to be considered when positioning an AR should include geographical location, surrounding substratum, proximity to natural habitats, depth and water conditions in the area of deployment [63]. Perkol-Finkel and Benayaho [71] found that community development of the experimental Pyramid-AR is suggested to be dependent on various factors, including its structural design, spatial orientation, depth, and age.

\section{III.8. Artificial Reefs Mimic Natural Reef Communities}

However, when substrates displaying different structural features are compared, within an AR or between an AR and a NR (natural reef), taxa assemblages will differ even after more than a century. Vertical habitats are able to accommodate specialized species that flourish under the conditions characterizing such habitats. The flourishing of ahermatypic corals on ARs, as opposed to their absence from the adjacent nearly horizontal NRs, was attributed to the current regime and low sedimentation load associated with inclined surfaces as well as to the ample overhangs [72, 73]. Horizontal surfaces of both ARs and NRs were characterized by the soft corals Nephthya sp. and Xenia sp., These taxa are characteristic of the Red Sea fauna and settle successfully on artificial surfaces there [71]. It is concluded by Perkol-Finkel et al. [74] that in the long run, the degree of resemblance of AR to NR communities will depend mainly on their respective structural features. Spatial orientation, complexity and facing of the substratum are the most important features to be considered, at least in tropical coral reef systems.

\section{III.9. Effect of Artificial Reefs on Fish Grazing}

Einbinder et al. [75] suggested that herbivorous fishes are attracted to the artificial reefs, creating a zone of increased grazing. Therefore, while planning deployment of such artificial reefs it is necessary to consider their overall influence on their natural surroundings, in order to maintain the natural community trophic dynamics. Rilov and Benayahu [68] observed that fish abundance and species richness at oil jetties were higher than in the natural coral reefs surrounding them, they further concluded that herbivorous fishes are attracted to artificial reefs. Herbivorous fishes are known to feed on algae that colonize the surface of the artificial reef structure [76].

\section{III.10. Novel Technology Approaches}

\section{III.10.1. Use of Coral Nubbins}

A valuable and novel approach was the attempt to develop numerous genetically identical colonies from a sin- gle genet, by isolating coral fragments to sizes no larger than a single or few polyps [28]. Subcloning minute fragments from a coral colony may reduce the stress inflicted on it and yield a high number of ramets amenable for various purposes [77-79]. Shafir et al. [78] have suggested using the term "nubbins" literally to characterize minute portions of coral colonies (a single isolated polyp or a coral fragment containing only a few polyps) and to term larger subclones of coral colonies as microcolonies, fragments, or ramets. Shafir et al. [44] further suggested that the successful production of coral colonies by nubbing minute sections from donor colonies could be the preferred methodology for establishing large numbers of genetically identical colonies (ramets) to be used as a valuable substance for different approaches, including restoration practices [42]. Not only are nubbins easily pruned from any part of a coral colony, but working with them is quick and yields significant quantities of source material within a short period. A set of 50 nubbins pruned from a 5 $\mathrm{cm}$-long branch can be established within $30 \mathrm{~min}$ [78].

\section{III.10.2. 3-D Structural Considerations}

The idea that the structural complexity of ramets may significantly influence its growth and regenerative ability received little attention, and, when discussed, its importance was attributed to ecological rather than to developmental concepts. Epstein and Rinkevich [80] have recently explored the conception that an architectural complexity threshold of isolated ramet is required for faster regeneration to a full colony structure. Rinkevich [29] and Epstein \& Rinkevich [80] found that the original architecture complexity of isolated ramets might influence their ability to instigate promptly these specific 3-D growth patterns. Similar outcomes were recorded by Soong and Chen (2003) working on Acropora, another branching genus. They found that fragments collected from the proximal part of Acropora colonies "were better" (in relation to transplantation measures) from the perspectives of fragment growth and branching.

\section{III.10.3. Molecular Biological Tools}

Ammar et al. [36] used a rational strategy for restoration of coral reefs by application of molecular biological tools to select sites for rehabilitation by asexual recruits. Diseases appearing in transplanted colonies and coral fragments have already been documented in at least two recent publications $[32,81]$. Not only the heat shock protein HSP70 is used as molecular biological indicator, but HSP90 as well, more over, the two metabolic enzymes fructose-1, 6-biphosphatase, and succinate-dehydrogenase from the azooxanthellate soft coral Dendronephthya klunzingeri were used for assessing health status of colonies sampled from two localities at Red Sea [36]. They found that, low levels of cDNAs were measured at a site characterized by high sedimentation rates.

\section{III.10.4. Chemical Signals and Surface Chemistry}

It is well known that chemical signals and communications may directly affect intracolony growth patterns and intraspecific interactions. Koh and Sweatman [82] revealed that extracts of Tubastrea faulkneri might reduce competition between existing corals and recruits by killing coral larvae. However, only very little attention has been given to this phenomenon in transplantation measures [25]. 
Still, the topics of surface chemistry $[43,83]$ and the possible inputs of toxic leachate from artificial substrates [43] were discussed and considered as important factors for enhancing natural recruitment. At least one artificial reef manufacturer (Reef Ball) recommended the addition of microsilica to concrete to provide a neutral $\mathrm{pH}$ surface. In addition, the organic and microbial biofilm that is quickly formed on any clear substrate that is immersed in seawater may provide negative settling cues, it is also well documented that initial colonizing microbial algal and invertebrate assemblages may affect settlement of coral larvae, moreover the chemical glycosaminoglycan was isolated from a coralline alga (Hydrolithon boergesenii) that signals Agaricia agaricites hummlis larvae to settle, the synthesized material, called "coral flypaper", proved effective for attracting larvae [58].

\section{III.11. Socio-Economic Aspects of Artificial Reefs}

\section{III.11.1. Social Issues Surrounding Artificial Reefs}

A review of the relevant literature has identified a number of social issues and outcomes - both positive and negative - that often surround the deployment and management of artificial reefs. The following sections outline these issues and, where possible, relate them to the potential deployment of artificial reefs.

\section{III.11.1.1. Enhanced Recreational Opportunities}

Artificial reefs can create or enhance recreational experiences in a number of ways [57]. First, they can add to the variety of fishing and/or diving experiences that exist within an area by providing different types of structure and attracting different kinds of marine life. Second, they can provide more accessible fishing and diving opportunities when placed close to access points, thereby enabling people who are limited by experience, boat size/horsepower, time, or money to enjoy recreational fishing or diving. Third, they can enhance the recreational experience or success rate by attracting or producing more marine life and increasing the probability of observing and/or catching fish. Fourth, they can help redistribute use throughout a given area thereby reducing user congestion and crowding.

\section{III.11.1.2. Social and Economic Impacts of Overfishing at} Artificial Reefs

Catch rates of fish around artificial reefs are often higher than catch rates in surrounding non-reef areas, leading to the perception of "enhanced" fisheries [57]. However, there is considerable debate over whether improved catch rates occur as a result of increased production (i.e., increased stock size) or through increased attraction and aggregation of preexisting fish stocks [54]. Fished artificial reefs have the potential to lead to overfishing if they increase the aggregation/attraction of existing stocks without increasing overall stock size [84].

\section{III.11.1.3. Changes in Property and Resource-Use Rights}

Because of incompatibilities between gear and structure, placing an artificial reef on a seabed where commercial fishers operate can automatically exclude this group from the area that was formally open access and their 'right' to use [57]. In Europe, artificial reefs are commonly used to exclude (illegal) trawling from sensitive habitats [85]. Changes to property and resource-use rights can also occur through management of artificial reefs. Artificial reefs often become the focal point of conflict within and across user groups, conflict is defined as goal interference attributed to another's behaviour and has been documented on numerous artificial reef sites worldwide [57].

A number of measures to minimize or manage conflict at artificial reefs have been proposed including: (1) selective access controls; (2) gear and catch restrictions; and (3) temporal or spatial segregation of users [86].

\section{III.11.1.4. Liability}

The potential for accidents resulting in personal injury or property damage at artificial reefs raises the issue of who should be held liable if such incidents occur. Because law suits have not yet passed through the courts [87, 88], answers to liability questions remain speculative. One question concerns whether the group or organization granted a permit to deploy an artificial reef will be capable of withstanding a liability suit. In Australia, private citizens and interest groups can apply for artificial reef permits, and may be required to provide liability insurance for deployed structures [89]. Liability on the managing agencies should be applicable only in terms of the artificial reef quality, the life span, and natural environmental conditions causing the accident, however, in case of man-made accidents like for example a ship accident, the liability should consider carefully the actual reasons of the accident.

\section{III.11.2. Economic Issues Surrounding Artificial Reefs}

This section examines the costs, impacts, and values associated with artificial reef development and questions whether the positive economic outcomes observed elsewhere will be realized with artificial reef deployment.

\section{III.11.2.1. Financial Costs of Reef Deployment and Management}

Costs associated with deployment will depend in part on the materials used. For example, preparing and sinking a decommissioned ship (the material most preferred by divers [90]), can be labour intensive [91] and can cost up to US $\$ 2$ million depending on the size of the vessel [92]. On-going maintenance costs can also be significant. It is estimated that the ongoing costs associated with maintaining the recentlyscuttled HMAS Brisbane in south Queensland will be on the order of AU\$200,000/year over 10 years [93]. Financial costs associated with artificial reef deployment and management have been covered in various ways. In the US, funds collected through an excise tax on fishing equipment under the Federal Aid in Sport Fish Restoration program (among other sources) have been used to create and manage artificial reefs for fisheries enhancement [84]. On the west coast of Canada, the Artificial Reef Society of British Columbia has used volunteer efforts (up to $8000 \mathrm{~h} / \mathrm{ship}$ ) to prepare decommissioned ships for use as artificial reefs. The British Columbia projects were funded through sale of scrap materials removed from the ships prior to scuttling as well as grants from governmental economic development programs and community fundraising [91]. In Australia, the HMAS Swan and HMAS Brisbane were "gifted" to Western Aus- 
tralia and Queensland, respectively, from the Commonwealth Government. The costs of scuttling the Swan were borne locally through fundraising, through the sale of scrap materials removed from the ship, and by the investment of approximately $10,000 \mathrm{~h}$ of volunteer labour [94, 95]. The AU\$5 million cost of preparing and scuttling the HMAS Brisbane was born primarily by the Queensland government [94]. Ongoing management costs of artificial reefs are often borne by reef users through user fees. For example, funds to cover the \$200,000/year management costs for the former HMAS Brisbane will be raised through a user fee for private and club divers, and through permitting fees charged to commercial dive companies who use the ref. [94]. Currently, visitors to the GBRMP on private vessels are not required to pay fees to use the park; however, visitors using commercial vessels are required to pay a \$5 "reef tax" collected by operators of commercial vessels. Although divers and fishers have shown a willingness to pay for artificial reef diving and fishing opportunities elsewhere [86].

\section{III.11.2.2. Economic Impact of Artificial Reefs}

One of the arguments frequently used in support of artificial reef development is that artificial reefs can have positive economic impacts on local communities through increased tourism and recreation activity. Economic impacts can occur at local, regional, or state levels and are measured in terms of employment, sales, income, and tax revenue [96]. Economic impacts are derived from expenditures on items such as user fees, charter fees, equipment, lodging, meals, fuel, and bait made by artificial reef users in the local, regional, or statewide area of interest. Re-spending of money in the local economy has a multiplier effect that results in the total economic impact being larger than the actual expenditures made [96].

Impacts on local economies due to artificial reef use can be significant. Johns et al. [86] estimated that the total economic impact of artificial reefs in Broward County (southeast Florida) from June 2000 to May 2001 amounted to US\$962 million in sales, \$502 million in income, and 16,800 full- and part-time jobs. Estimates of economic impact of artificial reefs for three other southeast Florida countries range from $\$ 131$ million to $\$ 419$ million in sales, $\$ 33$ million to $\$ 195$ million in income, and 1,800 to 6,000 jobs. In Australia, the total economic impact of the reef created by the former HMAS Swan in the initial 15 months of operation was estimated to be US\$1.39 million [94], and the Burnett Coast's Cochrane artificial reef in Queensland is estimated to inject approximately AU\$1 million dollars into the region annually' '[93].

\section{III.11.2.3. Economic Value of Artificial Reefs}

Economic value measures the value that users place on the opportunity and experience of using resources like artificial reefs. The extent to which users value artificial reefs is expressed by the money they spend to use the reefs plus any additional amount they would be willing to pay before foregoing the opportunity to use the reefs [57]. Measures of willingness to pay in excess of actual trip expenditures (commonly called consumer's surplus) have been used to estimate use value of artificial reefs. Johns et al. [86] estimated that the total use value of artificial reefs in southeast Florida in
2000-2001 was US\$8.59/person/day, which equates to an annual use value for all users of US\$85 million (compared to values of $\$ 12.47$ per person per day and $\$ 229$ million annually for natural reefs at the same location). The same author further found that recreational users' willingness to pay for new artificial reefs was significant (US\$27 million/year), but was lower than willingness to pay for protection of both existing artificial reefs (US\$85 million/year) and existing natural reefs (US\$229 million/year).

\section{III.11.2.4. A Strategy to Maximize the Socio-Economic Values of Artificial Reefs}

Attention must be paid to socio-economic issues if the values and benefits of artificial reefs are to be realized; without considerable advance planning, artificial reefs are unlikely to meet their socio-economic objectives [57]. To ensure that the socio-economic values of artificial reefs are realized, it is suggested that the planning, implementation, and management process should include the following steps: (1) assess the demand for artificial reefs (2) consult relevant stakeholders; (3) conduct a cost/benefit analysis; (4) decide whether to permit artificial reefs in the marine park; (5) involve stakeholders in the planning and management process; (6) set clear socio-economic goals and objectives; (7) consider social and economic issues in an appropriate management plan; (8) monitor and evaluate social and economic issues.

Potential deployment of artificial reefs will be a complex and controversial issue that will need a high level of management to ensure that artificial reef development produces positive social and economic benefits without diminishing the existing social, economic, and ecological values. However, most research on artificial reefs and artificial reef management is still ecological in nature, with few studies focusing on the socio-economic aspects [53].

\section{FUTURE OF REEF RESTORATION}

\section{IV.1. Future Considerations}

The long-term future of conservation biology is restoration ecology [97], however considerable effort is being invested in defining the conceptual bases for coral reef restoration $[7,19,42]$. Pursuing the success of restoration activities, ecological criteria that evaluate the status of coral reefs and biochemical/molecular markers that evaluate stress [36] should be developed and applied. Additionally, deciding which habitat in the reef should be restored may be as important as the extent of its restoration and should be defined and conceptually backed by experimental designs. Many restoration efforts are also limited on both financial grounds and available protocols and therefore should be highly focused. With more scientific background and concepts integrated with other biological disciplines (genetics, molecular biology, theoretical ecology, etc.), coral reef restoration measures will achieve far greater success than our present meager knowledge can.

\section{IV.2. Future Applications}

I- What we know now is:

1- Artificial reefs can be engineered effectively 
2- A number of targeted outcomes can be achieved (e.g Stopping illegal trawling; increasing biodiversity; providing tourist diving, fishing \& surfing; creating new artisanal and commercial fishing opportunities; colonizing structures by fishes and invertebrates).

3- If created on a large enough scale the 'reef effect' can be seen economically.

II- What we still don't is: 1- How to predict and manipulate epibiotic colonization 2- The exact trophic relationship between reef structures and mobile inhabitants 3- How to design structures to maximize benefit for target species (lots of expert ideas, not too much detailed biological knowledge) 4- How to model the biological and physical development of artificial reefs (for planning \& design).

III- What do the scientists, engineers, planners \& decision makers need to do is: 1- Understand the processes in creation of artificial reef habitat and the reasons why an artificial reef should be developed 2- Link the biological, physical and economic issues within reef development 3- Continue biological and engineering research to refine reef design and modeling 4- Communicate better!

\section{CONCLUSIONS}

- In a healthy reef system which has not been physically damaged, an impacted area might be expected to recover naturally to its pre-disturbance state along a successional trajectory. If degradation is sufficiently severe or spatially extensive, then active restoration e.g. transplantation, in combination with management actions to reduce anthropogenic stress are necessary. Recoverability depends on the stressor, the impacted species/community and the temporal and spatial intensities of the stressor

- A coral nursery may be considered as a pool for local species that supplies reef-managers with unlimited coral colonies for sustainable management

- Artificial reef is any structure built or placed on the sea bed, water column or floating on its surface, with the purpose of creating a new attraction to scuba divers or to concentrate or attract plants or animals for fishing purposes

- Artificial reefs are used for: (1) Tourism [SCUBA diving, recreational angling, surfing and beach enhancement\} (2) Fisheries (3) Nature conservation (4) $\underline{\text { Science }}$

- Artificial reefs can have positive economic impacts which is significant and may be several hundreds of million dollars per year

- For future application, need is urgent for:

1. Link the biological, physical and economic issues within reef development

2. Continue biological and engineering research to refine reef design and modelling

\section{REFERENCES}

[1] A. J. Edwards and E. D. Gomez, in Reef restoration concepts and Guidelines: making sensible management choices in the face of un- certainty, Coral Reef Targeted Research \& Capacity Building for Management Programme, St Lucia: Australia, 2007, p. 38.

[2] Status of Coral Reefs of the World Report, C. Wilkinson, Ed. 2004 Available from: http://www.aims.gov.au

[3] H.S.J. Cesar, Ed. in Collected Essays on the Economics of Coral Reef, CORDIO: Sweden, 2000, pp. 244.

[4] W.F. Precht, Ed. in Coral Reef Restoration Handbook, Boca Raton: CRC Press, 2006, pp. 363.

[5] S. Job, M. Schrimm, and R. Morancy, "Reef Restoration: Practical guide for management and decision-making", Carex Environnement, Ministère de l'Écologie et du Développement Durable, IFRECOR, 2003, pp. 32.

[6] M. Omori, and S. Fujiwara, in Manual for restoration and remediation of coral reefs, Nature Conservation Bureau. Japan: Ministry of Environment, 2004, pp. 1-84.

[7] N. Epstein, R.P.M. Bak, and B. Rinkevich, "Applying forest restoration principles to coral reef rehabilitation", Aquatic. Conservation., 2003. vol. 13, pp. 387-395.

[8] C. Simenstad, D. Reed, and M. Ford, "When is restoration not? Incorporating landscape-scale processes to restore self-sustaining ecosystems in coastal wetland restoration”, Ecological Engineering, 2006, vol. 26, pp. 27-39.

[9] M. Elliott, D. Burdon, K.L. Hemingway, S.E. Apitz, and S.E., Estuarine, "coastal and marine ecosystem restoration: confusing management and science - A revision of concepts, Estuarine". Coastal and Shelf Science, 2007, vol. 74, pp. 349-366,.

[10] Emu Ltd. Marine Aggregate Restoration and Enhancement: Strategic Policy Overview. Report No. 04/J/01/06/0548/0437. Emu Ltd. on behalf of The British Marine Aggregate Producers Association, the Crown Estate and English Nature.

[11] G. Marlin, The marine life information network for britain and Ireland: Online glossary of scientific terms 2005, Available from: http://www.marlin.ac.uk/Glossaries/Gen_Glossary.htm

[12] J.S. Collie, S.J. Hall, M.J. Kaiser, and I.R. Poiner, "A quantitative analysis of fishing impacts on shelf-sea benthos", Journal of Animal Ecology, 2000, vol. 69, pp. 785-798.

[13] F.J. Madgwick, and T.A. Jones, Europe. Restoration in Practice, Perrow, M.R., Davy, A.J. Eds., in Handbook of Ecological Restoration. Cambridge: Cambridge University Press, 2002, vol. 2. pp. $32-56$.

[14] A.D. Bradshaw, Introduction and philosophy. in Handbook of Ecological Restoration. Principles of Restoration, M.R. Perrow, A.J. Davy, Eds. Cambridge: Cambridge University Press, 2002, vol. 1. pp. 3-9.

[15] R.C. Baird, "On sustainability, estuaries and ecosystem restoration: the art of the practical", Restoration Ecology, 2005, vol. 13, pp. 154-158, 2005.

[16] R.J. Livingston, Restoration of Aquatic Ecosystems, Boca Raton, Florida: Taylor and Francis, 2006, p. 423.

[17] F.B. Van Cleve, T. Leschine, T. Klinger, and C. Simenstad, "An evaluation of the influence of natural science in regional-scale restoration projects", Environmental Management, 2006, vol. 37, pp. 367-379, 2006

[18] M.S. Fonseca, W.J. Kenworthy, B.E. Julius, S. Shutler, and S Fluke, Sea grasses. in Handbook of Ecological Restoration, Restoration in Practice, Vol. 2, M.R. Perrow, and A.J. Davy, Eds. Cambridge: Cambridge University Press, 2002, pp. 149-170.

[19] W.C. Jaap, "Coral reef restoration", Ecological Engineering, vol. 15 , pp. $345-364,2000$

[20] H. Schuhmacher, P. van Treeck, M. Eisinger, and M. Paster, "Transplantation of coral fragments from ship groundings on electrochemically formed reef structures", Proceedings of the 9th International Coral Reef Symposium, Indonesia, 2002, vol. 2, pp. 983-990.

[21] W.F. Precht, D.R. Deis, and A.R. Gelber, Damage assessment protocol and restoration of coral reefs injured by vessel groundings, Proceedings of the 9th International Coral Reef Symposium, Indonesia, 2002, vol. 2, pp. 963-968.

[22] M.W Miller, and J. Barimo, Assessment of juvenile coral populations at two reef restoration sites in the Florida keys National Marine Sanctuary: indication of success? Bulletin of Marine Sciences, 2001, vol. 69: pp. 395-405.

[23] D. Lirman, and M.W. Miller, "Modeling and monitoring tools to assess recovery status and convergence rates between restored and undisturbed coral reef habitats", Restorstion Ecology, vol. 11, pp. 448-456, 2003 
[24] J.W. Milon and R.E. Dodge, "Applying habitat equivalency analysis for coral reef damage assessment and restoration". Buletin of Marine Science, vol. 69, pp. 975-988, 2001.

[25] H.T. Yap, "Differential survival of coral explants on various substrates under elevated water temperatures", Marine Pollution Bulletin, vol. 49, pp. 306-312, 2004.

[26] M. Omori, T. Aota, A. Watanuki, and H. Toniguchi, "Development of coral restoration method by mass culture, transplantation and settlement of coral larvae", Proceedings of the 1st Coral Reef Conference, Palao, 2004, pp. 30-38.

[27] M. Hatta, and K. Iwao, "Metamorphosis induction and its possible application to coral seedlings production", Recent Advances in Maine Science and Technology, 2002, pp. 465-470.

[28] K. Soong and T. Chen, "Coral transplantation: regeneration and growth of Acropora fragments in a nursery", Restoration Ecology, vol. 11, pp. 62-71, 2003.

[29] B. Rinkevich, "Steps towards the evaluation of coral reef restoration by using small branch fragments", Marine Biology, vol. 136, pp. 807-812, 2000.

[30] A. Bowden-Kerby, "Low-tech coral reef restoration methods modeled after natural transplantation processes", Bulletin of Maine Science, vol. 69, pp. 915-931, 2001.

[31] I. Nagelkerken, S. Bouma, S. Vandenakker, and R.P.M. Bak, "Growth and survival of unattached Madracis mirabilis fragments transplanted to different reef sites, and the implication for reef rehabilitation", Buletin of Marine Science, 2000, vol. 66, pp. 497505 .

[32] L. J. Raymundo, "Mediation of growth by conspecific neighbors and the effects of site in transplanted fragments of the coral Porites attenuata Nemenzo in the central Philippines", Coral Reefs, 2001, vol. 20 , pp. 263-272.

[33] J. Tamelander, D. Obura, Coral reef rehabilitation: feasibility, benefits and need, In: Coral Reef Degradation in the Indian Oceans: Status Report 2002; Linden, O., Souter, D., Wilhelmsson, D., Obura, D., Eds., CORDIO: Kalmar (Sweden), 2002, pp 263271.

[34] J. Tamelander, S. Visram, and D. Obura, "Prospects for coral recovery through transplantation and natural recruitment, Kenya", Proceedings of the 9th International Coral Reef Symposium, Indonesia, 2002, vol. 2, pp. 991-996.

[35] U. Lindahl, "Coral reef rehabilitation through transplantation of staghorn corals: effects of artificial stabilization and mechanical damages", Coral Reefs, vol. 22: pp. 217-223, 2003.

[36] M.S.A. Ammar, E.M. Amin, D. Gundacker, and W.E.G. Mueller, "One rational strategy for restoration of coral reefs: application of molecular biological tools to select sites for rehabilitation by asexual recruits", Marine Pollution Buletin, vol. 40, pp. 618-627, 2000.

[37] M.S.A. Ammar, and M.A. Mahmoud, "A new innovated and cheep model in building artificial reefs", Egytian Journal for Aquatic Research, vol. 31, pp. 105-118, 2005.

[38] L.C. Becker, and E. Mueller, "The culture, transplantation and storage of Montastraea faveolata, Acropora cervicornis and Acropora palmata: what we have learned so far", Bulletin Marine Science, vol. 69, pp. 881-896, 2001.

[39] M.G. Sabater, and H.T. Yap, "Growth and survival of coral transplants with and without electrochemical deposition of CaCO3", Journal of Experimental Maine Biology and Ecology, vol. 272, pp. 131-146, 2002.

[40] M.G. Sabater, and H.T. Yap, "Long-term effects of induced mineral accretion on growth, survival and corallite properties of Porites cylindrica Dana", Journal of Experimental. Maine Biology and Ecology, vol. 311, pp. 355-374, 2004.

[41] H.E. Fox, J.S. Pet, R. Dahuri, and R.L. Caldwell, "Recovery in rubble fields: long-term impacts of blast fishing", Marine Pollution Bulletin, vol. 46, pp. 1024-1031, 2003.

[42] N. Epstein, R.P.M. Bak, and B. Rinkevich, "Strategies for gardening denuded coral reef areas: the applicability of using different types of coral material for reef restoration". Restoration Ecology, vol. 9, pp. 432-442, 2001.

[43] H.T. Yap, "The case for restoration of tropical ecosystems", Ocean Coastal Management, vol. 43, pp. 841-851, 2000.

[44] S. Shafir, J. van Rijn, and B. Rinkevich, "Nubbing of coral colonies: a novel approach for the development of inland broodstocks", Aquatic Science and Conservation, vol. 3, pp. 183-190, 2001.

[45] H.E. Fox, J.S. Pet, R. Dahuri, and R.L. Caldwell, "Coral reef restoration after blast fishing in Indonesia", Proceedings of the 9th In- ternational Coral Reef Symposium, Indonesia, 2002, vol. 2, pp. 969-976.

[46] T.J. Goreau, J.M. Cervino, and R. Pollina, "Increased zooxanthellae numbers and mitotic index in electrically stimulated corals", Symbiosis, vol. 37, pp.107-120, 2004.

[47] D.F. Gleason, D.A. Brazeau, and D. Munfus, "Can self-fertilizing coral species be used to enhance restoration of Caribbean reefs?", Buletin of Marine Science, vol. 69, pp. 933-943, 2001.

[48] A.L. Ortiz-Prosper, A. Bowden-Kerby, H. Ruiz, O. Tirado, A. Caban, G. Sanchez, and J.C. Crespo, "Planting small massive corals on small artificial concrete reefs or dead coral heads", Buletin of Marine Science, vol. 69, pp. 1047-1051, 2001.

[49] B. Rinkevich, The coral gardening concept and the use of underwater nurseries: lessons learned from silvics and silviculture. In: Coral Reef Restoration Handbooks, The Rehabilitation of an Ecosystem Under Siege; Precht, W. E. Ed.; 2005, 291-300, Press.

[50] D. Peterson, and R. Tollrian, "Methods to enhance sexual recruitment for restoration of damaged reefs", Buletin of Marine Science, vol. 69, pp. 989-1000, 2001

[51] E.H. Borneman, and J. Lowrie, "Advances in captive husbandry and propagation: an easily utilized reef replenishment means from the private sector?", Bulletin of Maine Science, vol. 69, pp. 897913, 2001.

[52] T. Heeger, and F. Sotto, Eds. in Coral Farming: A Tool for Reef Rehabilitation and Community Ecotourism. German Ministry of Environment (BMU), German Technical Cooperation and Tropical Ecology program (GTZ-TÖB), Philippines, 2007, p. 94.

[53] M. Baine, "Artificial reefs: a review of their design, application, management and performance", Ocean \& Coastal Management, vol. 44, pp. 241-259, 2001.

[54] R. Pears, and D.Mc.B. Williams, Potential effects of artificial reefs on the GREAT BARRIER reef. Cooperative Research Centre for the great barrier Reef World Heritage Area technical report 60 . Townsville: James Cook University, 2005.

[55] M.D.J. Sayer, and T.A. Wildin, "Planning, licensing, and stakeholder consultation in an artificial reef development: the Loch Linnhe reef, a case study", ICES Journal of Marine Science, vol. 59, S178-85, 2002.

[56] L. Gravitz, The double-edged lure of man-made reefs, Cyber Diver News Network 2000, Available from: http://www.cdnn.info/article/ artificial_reefs/ artificial_reefs.html [Accessed 22 July 2005].

[57] S.G. Sutton, and S.L Bushnell, "Socio-economic aspects of artificial reefs: considerations for the great barrier reef marine park", Ocean and Coastal Management, vol. 50, pp. 829-846, 2007.

[58] B. Rinkevich, "Conservation of coral reefs through active restoration measures: recent approaches and last decade progress", Environtal Science and Technology., vol. 39, pp. 4333-4342, 2005.

[59] H. Schuhmacher, "Use of artificial reefs with special reference to the rehabilitation of coral reefs", Bonner Zoological Monographs, vol. 50, pp. 81-108, 2002.

[60] H.E. Fox and J.S. Pet, "Pilot study suggests viable options for reef restoration in Komodo National Park", Coral Reefs, vol. 20, pp. 219-220, 2001

[61] L. Schillak, M.S.A. Ammar, and W.E.G. Mueller, "Transplantation of coral species to electrochemical produced hard substrata: (Stylophora pistillata Esper, 1797 and Acropora humilis Dana, 1846)", ACP-EU Fisheries Research Report, 2001, 10: 68-84. Mombasa, Kenya, Brussels, 19-22 June 2000.

[62] M.S.A. Ammar, "Improvement of the molecular and physiological behavior of the reef coral Stylophora pistillata at Hurghada, Red Sea, Egypt by using the ARCON substrate", Journal of the Egyptian Academic Soceity for Environmental Development, vol. 2, pp. 205-219, 2001.

[63] Y.P. Sheng, "Physical characteristics and engineering at reef sites". in Artificial Reef Evaluation With Application to Natural Marine Habitat, W. Seasman, Jr., Ed. Boca Raton, FL: CRC press, 2000, pp. 51-94.

[64] I.B. Svane, and J.K. "Peterson, on the problems of epibiosis, fouling and artificial reefs, a review", Marine Ecology, vol. 33, pp. 169-188, 2001.

[65] E.A.S. Godoy, T.C.M. Almeida, and I.R. Zalmon, "Fish assemblages and environmental variables on an artificial reef north of Rio de Janeiro, Brazil", ICES Journal of Marine Science, vol. 59, pp. 138-143, 2002. 
[66] M. Falcão, M.N. Santos, M. Vicente and C.C. Monteiro, "Biogeochemical processes and nutrient cycling within an artificial reef off Southern Portugal", Marine Environmental Research, vol. 63, pp. 429-444, 2006.

[67] S. Perkol-Finkel, and Y. Benayahu, "Community structure of stony and soft corals on vertical unplanned artificial reefs in Eilat (Red Sea): comparison to natural reefs", Coral Reefs, vol. 23, pp. 195205, 2004.

[68] G. Rilov, and Y. Benayahu, "Fish assemblage on natural versus vertical artificial reefs: the rehabilitation perspective", Marine Biology, vol. 136, pp. 931-942, 2000.

[69] S. Perkol-Finkel, Y. Benayahu, "The role of differential survival patterns in shaping coral communities on neighboring artificial and natural reefs", Journal of Experimental Marine Biology and Ecology, 2009, 369 (1): 1-7.

[70] W. Seaman, and A.C. Jensen, "Purposes and practices of artificial reef evaluation". in Artificial Reef Evaluation with Application to Natural Marine Habitats, W. Seaman, Ed., Boca Raton, FL: CRC Press LLC, 2000, pp. 2-19.

[71] S. Perkol-Finkel, and Y. Benayahu, "Recruitment of benthic organisms onto a planned artificial reef: shifts in community structure one decade post deployment", Marine Environmental Research, vol. 59: pp. 79-99, 2005.

[72] D. Fenner, and K. Banks, "Orange cup coral Tubastrea coccinea invades Florida and the Flower Garden Banks, Northwestern Gulf of Mexico", Coral Reefs, 2004, vol. 23, pp. 505-707, 2004.

[73] S. Perkol-Finkel, N. Shashar, O. Barnea, R. Ben-Daviv-Zaslaw, U. Oren, and T. Reichart, "Fouling reefal communities on artificial reefs: does age matter?", Biofouling, vol. 21, pp. 127-140, 2005.

[74] S. Perkol-Finkel, N. Shashar, and Y. Benayahu, "Can artificial reefs mimic natural reef communities? The roles of structural features and age", Marine Environmental Research, vol. 61, pp. 121$135,2006$.

[75] S. Einbinder, A. Perelberg, O. Ben-Shaprut, M.H. Foucart, and N. Shashar, "Effects of artificial reefs on fish grazing in their vicinity: evidence from algae presentation experiments", Marine Environmental Research, vol. 61, pp. 110-119, 2006.

[76] I.D. Williams, and N.V.C. Polunin, "Large-scale associations between macro algal cover and grazer biomass on mid-depth reefs in the Caribbean", Coral Reefs, vol. 19, pp. 358-366, 2001.

[77] L. Bongiorni, S. Shafir, and B. Rinkevich, "Effects of particulate mattervreleased by a fish farm (Eilat, Red Sea) on survival and growthvof Stylophora pistillata coral nubbins", Maine Pollution Buletin., vol. 46, pp. 1120-1124, 2003.

[78] S. Shafir, J. van Rjin, and B. Rinkevich, "The use of coral nubbins in coral reef ecotoxicology testing", Biomoecular Engineering, vol. 20, pp. 401-406, 2003.

[79] T. A. Schlacher, J. Stark, A.B.P. Fischer, "Evaluation of artificial light regimes and substrate types for aquaria propagation of the staghorn coral Acropora solitaryensis", Aquaculture, 2007, 269 (1): 278-289.

[80] N. Epstein, and B. Rinkevich, "From isolated ramets to coral colonies: the significance of colony pattern formation in reef restoration practices", Basic Applied Ecology., vol. 2, pp. 219-222, 2001.

[81] A.W. Bruckner, and R.J. Bruckner, "Condition of restored Acropora palmata fragments off Mona Island, Puerto Rico, 2 years after the Fortuna Reefer ship grounding", Coral Reefs, vol. 20, pp. 235243, 2001.

[82] E.G.L. Koh, and H. Sweatman, "Chemical warfare among scleractinians: bioactive natural products from Tubastraea faulkneri Wells kill larvae of potential competitors", Journal of Experimental Marine Biology and Ecology, vol. 251, pp. 141-160, 2000.
[83] R.E. Spieler, D.S. Gilliam, and R.L. Sherman, "Artificial substrate and coral reef restoration: what do we need to know to know what we need", Bulletin of Marine Science, vol. 69, pp. 1013-1030, 2001.

[84] E. Jebreen, "An investigation into the effects of artificial reefs on fish stocks. queensland department of primary industries", 2005, Available from: /http://www.dpi.qld.gov.au/far/9279.htmS [Accessed: 22 August 2005].

[85] M. Baine, and J. Side, "Habitat modification and manipulation as a management tool. Reviews in Fish Biology and Fisheries", 2003, vol. 13, pp. 187-99, 2003.

[86] G.M. Johns, V.R. Leeworthy, F.W. Bell, and M.A. Bonn, "Socioeconomic study of reefs in Southeast Florida-final report. Report prepared for Broward County, Palm Beach County, Miami-Dade County, Monroe County, Florida Fish and Wildlife Conservation Commission and National Oceanic and Atmospheric Administration", Hazen and Sawyer: Environmental Engineers and Scientists, 2001.

[87] R.R. Lukens, "Artificial reefs: habitat for marine resources national policy?" Proceedings from the Florida artificial reef summit, 01. W. Horn, Ed, Florida: Fort Lauderdale, 2001, pp. 16-20.

[88] D.M. Schroeder, and M.S. Love, "Ecological and political issues surrounding decommissioning of offshore oil facilities in the Southern California Bight”, Ocean and Coastal Management, vol. 47, pp. 21-48, 2004.

[89] Australian Government Department of Environment and Heritage, Artificial Reefs, Department of the Environment and Heritage, 2002, Available from: /http://www.deh.gov.au/coasts/pollution/ dumping/reefs.html [Accesses: 29 July 2005].

[90] R.B. Ditton, H.R. Osburn, T.L. Baker, and C.E. Thailing, "Demographics, attitudes, and reef management preferences of sport divers in offshore Texas waters", ICES Journal of Marine Science, vol. 59, S186-91, 2002.

[91] T. Enemark, Recycling economics from the perspective of artificial reef creation: remarks made to the ship recycling conference, Philadelphia, September 11, 2001. Artificial Reef Society of British Columbia 2001, Available from: /http://www.artificialreef.bc.ca/ Resources/Remarks\%20for\%20Philedelphia\%20Ship\%20Recycling\%20Conference.pdfS [Accessed 22 July 2005].

[92] R. Hess, D. Rushworth, M.V. Hynes, and J.E. Peters, Disposal options for ships. RAND, 2001, Available from: http://www.rand.org/ publications/MR/MR1377/S [accessed 22 July 2005].

[93] Queensland Department of Primary Industries and Fisheries. Artificial attraction. FISH Newsletter, 2004, Available from: /http://www.dpi.qld.gov.au/ fish/14257.htmlS [Accessed: 22 August 2005].

[94] R.K. Dowling, and J. Nichol, "The HMAS Swan artificial dive reef". Annals of Tourism Research, vol. 28, pp. 229-32, 2001.

[95] Queensland Environment Protection Agency, Sink the Brisbane. Environmental Protection Agency/Queensland Parks and Wildlife Service. Available from: http://www.epa.qld.gov.au/about_the_ epa/coming_events/sink_the_brisbane/ [Accessed 22 July 2005].

[96] J.W. Milon, S.M. Holland, and G. Relini, "Artificial reef evaluation with application to natural marine habitats". in Social and Economic Evaluation Methods, W. Seaman, Jr, Ed. Boca Raton, FL: CRC Press, 2000, pp. 165-94.

[97] T.P. "Young, Restoration ecology and conservation biology", Biological Conservation, vol. 92, 2000, pp. 73-83.

(C) Mohammed Shokry Ahmed Ammar; Licensee Bentham Open.

This is an open access article licensed under the terms of the Creative Commons Attribution Non-Commercial License (http://creativecommons.org/licenses/by-nc/3.0/) which permits unrestricted, non-commercial use, distribution and reproduction in any medium, provided the work is properly cited. 